\title{
The effects of physical training on insulin secretion and effectiveness and on glucose metabolism in obesity and Type 2 (non-insulin-dependent) diabetes mellitus
}

\author{
M. Krotkiewski, P. Lönnroth, K. Mandroukas, Z. Wroblewski, M. Rebuffé-Scrive, \\ G. Holm, U.Smith and P. Björntorp
}

Departments of Rehabilitation Medicine and Plastic Surgery and the Clinical Metabolic Laboratory of Departments of Medicine I and II, Sahlgren's Hospital, University of Göteborg, Göteborg, Sweden

\begin{abstract}
Summary. Obese subjects with normal glucose tolerance $(n=55)$, and, in another study, a group of patients with Type 2 (non-insulin-dependent) diabetes $(n=33)$, and controls $(n=13)$ matched for body weight and age but with normal glucose tolerance, participated in an individualized physical training program for 3 months. Under controlled dietary conditions, metabolic studies were performed before and in steady state after the last exercise session after training in the subjects showing signs of physical training in $\mathrm{VO}_{2} \max$ and heart rate measurements. No changes occurred in body weight, body cell mass, body fat or adipose tissue cellularity. Oral glucose tolerance was improved in the patients with diabetes mellitus only. In both diabetic and control subjects initially elevated C-peptide concentrations decreased, while low C-peptide values increased and which was particularly pronounced in diabetic subjects with subnormal values. Peripheral insulin values did not change. Glucose disposal rate measured with the glucose clamp technique was similar in diabetic patients and control subjects. An improvement was seen at both submaximal and maximal insulin levels in both groups, correlating with improvement in glucose tolerance in the diabetic subjects.

No changes were found in adipocytes in insulin binding or
\end{abstract}

the antilipolytic effect of insulin at submaximal insulin levels, but there was a normalization of a decreased glucose incorporation into triglycerides.

These results indicate that both insulin secretion and effectiveness are altered by physical training in different ways in different clinical entities. They suggest that in insulin resistant conditions with high insulin secretion (as indicated by high Cpeptide concentrations) the increased peripheral insulin sensitivity is followed by a decreased insulin secretion. This is not associated with an improvement of glucose tolerance. In Type 2 diabetes with low insulin secretion, an increased insulin secretion results from physical training, perhaps due to accompanying sensitization of the autonomic nervous system. Peripheral insulin concentrations are not altered, suggesting that the extra insulin produced is captured by the liver. This mechanism, as well as the improved peripheral insulin responsiveness seen in the whole body and also seen at the cellular level, probably both contribute to an improvement in glucose tolerance.

Key words: Type 2 diabetes, obesity, physical training, glucose tolerance, insulin, C-peptide, glucose clamp, insulin binding, adipocytes.
By tradition exercise is one of the basic principles in the therapy of diabetes mellitus to stabilize glucose homeostasis and to improve diabetic control. The documentation of such effects is, however, surprisingly incomplete. Only recently have well-controlled studies been performed with the purpose of trying to better define the place of regular exercise and physical training in the therapy of diabetes mellitus. In general, the effects on glucose metabolism have been moderate, of short duration, or even lacking (1-3), in spite of the now well-established fact that increased levels of plasma insulin are clearly lowered by physical training due to an increased peripheral insulin sensitivity (4). These findings suggest that, at best, only a subgroup of Type 2 (non-insulin-dependent) patients benefits from physical training.
In the present work this possibility was elucidated by subjecting sufficiently large groups of diabetic and obese subjects and controls to physical training to allow an analysis of effects in subgroups, characterized in terms of glucose intolerance as well as secretion, peripheral uptake and effectiveness of insulin. Changes in these variables were registered after physical training in an attempt to explain how alterations in glucose tolerance are brought about.

\section{Subjects and methods}

\section{Subjects examined}

Study I. Fifty-five obese women were recruited from the Obesity Outpatient Clinic at the University Hospital. They were all in a non-dieting, weight-stable condition, body weight changing less than $2 \mathrm{~kg}$ 
within the preceeding three months. They all had a non-diabetic glucose tolerance test (for definition, see below). Non-obese control women $(n=15)$ were found among volunteers obtained by an advertisement in a local newspaper. They were weightstable, healthy and non-dieting. Most of these women were physically active to some extent, but none was training regularly. No subjects were taking contraceptive drugs or any other drugs of known importance for the examined variables. All the controls had normal glucose tolerance tests. The body composition and other characteristics of these subjects are seen in Table 1.

Study II. Forty-six subjects, 34 women and 12 men, were recruited from the Diabetes or Obesity Outpatient Clinics at the University Hospital or by an advertisement in a local newspaper for participation in the study. The general characteristics of the patients are summarized in Table 2. The subjects had a history of weight stability ( \pm$2 \mathrm{~kg}$ body weight) during at least the preceeding 3 months. They were then observed for about two months to ensure weight stability by body weight recordings at least twice during this period. All were actively employed but had a rather sendentary way of life, not training regularly or being engaged in any kind of sports activity. None was on a diet except patients with known Type 2 diabetes (12 men and 12 women). These subjects were also treated with sulfonylurea drugs for at least 1 year. This medication was not changed during the period of physical training, and no subject was on insulin treatment. No subject had obvious signs or symptoms of diabetic complications, and the mean diabetes duration was 5.1 years. Of the 46 subjects participating in study II glucose tolerance tests revealed that 13 had a normal glucose tolerance (for definition, see below), while the remaining $(n=33)$ had decreased glucose tolerance of varying degrees including overt clinical diabetes mellitus $(n=24)$ and were examined in one group.

Five days prior to, as well as after the physical training period, the patients were placed on a diet estimated to give caloric balance, viz. $35 \mathrm{kcal}$ per $\mathrm{kg}$ ideal body weight. Ideal body weight was taken from the Metropolitan Life Insurance tables as the mean of the value given at medium frame. The diet consisted of about 15,40 and $45 \%$ of protein, fat and carbohydrate, respectively, and was identical before and after the period of physical training. Glucose tolerance tests and the euglycaemic glucose clamp were performed under these conditions on the fourth day or later after the last exercise session. All participants were instructed not to change their ordinary diet during the training period.

All participants gave their informed consent before entering into the examinations. The study was approved by the Ethical Committee at the University of Göteborg.

Oral glucose tolerance test $(O G T T)$. One hundred grams glucose, dissolved in $200 \mathrm{ml}$ lemon flavoured water, were taken orally in the morning in the overnight fasting state. The subjects were asked not to smoke that morning and arrive to the laboratory without rush. Blood samples were drawn before and at $30,60,90$ and $120 \mathrm{~min}$ after glucose ingestion from an indwelling catheter in an antecubital vein for enzymatic determination of blood glucose (GLOX, Kabi, Sweden), plasma insulin and connecting C-peptide by commercially available radioimmunoassay methods(Phadebas Pharmacia, Uppsala, Sweden and Novo, Copenhagen, Denmark respectively). The error of these methods are $<0.05 \%$ in the mean range of the analysed results. With this test the subjects were classified as diabetic if at least three glucose values exceeded the ranges proposed by the Diabetes Data Group [5].

\section{Body composition determinations}

Body weight was recorded to the nearest $0.1 \mathrm{~kg}$ and height to the nearest $\mathrm{cm}$. Total body potassium was measured in a whole body counter, after correction for the shielding effect of body fat [6]. Lean body mass (LBM) and body fat were then calculated as described by Forbes et al. [7].

Subcutaneous needle biopsies of adipose tissue were performed in the epigastric, hypogastric, femoral, gluteal and upper arm regions for determinations of fat cell weight with a microscopic method [8]. These values were averaged. Total fat cell number was estimated by dividing body fat with the average fat cell weight.

\section{Exercise test and determination of maximal oxygen uptake $\left(\mathrm{VO}_{2}\right.$ max)}

A Monark (Varberg, Sweden) mechanically braked bicycle ergometer was used for the exercise tests. The maximal oxygen uptake measurements were performed by stepwise work load increase until exhaustion [9] with continuous ECG and frequent blood pressure recordings. Expired air was collected in Douglas bags, and the volume and $\mathrm{O}_{2}$-content measured in a Beckman OM-11 instrument during the last minutes of the maximal work load. The test was repeated once at another occasion to ensure reproducibility, which was $\pm 3 \%$.

Heart rate and blood pressure at predetermined submaximal work loads $(50 \mathrm{~W}$ and $100 \mathrm{~W})$ were also recorded for comparisons before and after the physical training programme.

\section{Physical training}

The groups were trained for 3 months, three times a week. The duration of each training session was $50 \mathrm{~min}$, starting with $10-15 \mathrm{~min}$ warm-up including walking, jogging and calisthenics of light intensity, and including exercises with all parts of the body. The programme then continued with alternating heavy and light periods. The heavy intervals were performed on a bicycle ergometer, lasted for $4 \mathrm{~min}$, and were standardized for each patient to reach $80-90 \%$ of the individual $\mathrm{VO}_{2} \max$, commencing with a submaximal work load. This level was adjusted upwards as the conditioning of the participants increased during the training to be kept at an $80-90 \%$ level.

\section{Euglycaemic glucose clamp measurements}

Arterial blood was drawn from the radial artery and fed into an automatic, continuous glucose monitoring system (Gambro, Lund, Sweden), which measures the blood glucose levels every minute. A solution of $0.4 \mathrm{IU} / \mathrm{ml}$ of porcine insulin (Actrapid, Novo, Copenhagen, Denmark) dissolved in isotonic saline was infused into the subclavian vein through a catheter introduced into a brachial vein with a constant infusion pump (IMED $922 \mathrm{H}$, San Diego, Calif., USA).

The insulin was given at two infusion rates $(0.08$ and $0.60 \mathrm{IU} \cdot \mathrm{kg}$ body weight ${ }^{-1} \cdot \min ^{-1}$ ). The plasma insulin levels obtained by these infusions were not different before and after training $(105.5 \pm 7.2$ and $107.3 \pm 7.4$ at low level and $1357.6 \pm 103.9$ and $1410.3 \pm 69.9 \mathrm{mU} / 1$ at high level - means \pm SEM, before and after training respectively). Blood glucose levels were kept constant by the infusion centrally of a $40 \%(\mathrm{w} / \mathrm{v})$ solution of glucose containing $100 \mathrm{mmol} / \mathrm{l}$ of potassium, $20 \mathrm{mmol} / 1$ of magnesium and $30 \mathrm{mmol} / 1$ of phosphate. Blood for plasma insulin levels was drawn every $5 \mathrm{~min}$. When steady state was reached, determined by the coefficients of variation (mean $\pm S D$ ) for insulin and glucose, the glucose disposal rate was calculated during the last 20-min period of the low and high insulin infusions respectively. The duration of each of these periods was $60 \mathrm{~min}$. These studies were performed in a subgroup of 13 control and 10 diabetic subjects who gave their informed consent.

\section{Adipose tissue studies}

After fasting overnight, a subcutaneous adipose tissue biopsy was taken from the hypogastric region in local anaesthesia (Lidocaine, Astra, Sweden). Care was taken not to infiltrate the tissue to be excised.

\section{Insulin binding}

Fat cells were liberated by incubating the biopsies in medium 199 containing collagenase $(1.5 \mathrm{mg} / \mathrm{ml})$ and $50 \mathrm{~g} / 1$ of bovine serum albumin 
Table 1. Characteristics of examined groups (Study I)

\begin{tabular}{|c|c|c|c|}
\hline \multirow[b]{3}{*}{ Age (years) } & \multirow[t]{2}{*}{$\begin{array}{l}\text { Control subjects } \\
(n=15)\end{array}$} & \multicolumn{2}{|l|}{$\begin{array}{l}\text { Obese subjects } \\
(n=55)\end{array}$} \\
\hline & & $\begin{array}{l}\text { Before } \\
\text { training }\end{array}$ & $\begin{array}{l}\text { After } \\
\text { training }\end{array}$ \\
\hline & $37.1 \pm 1$ & $38.5 \pm 2.0$ & - \\
\hline Height $(\mathrm{cm})$ & $169.0 \pm 2$ & $165.9 \pm 1.3$ & - \\
\hline Weight (kg) & $62.0 \pm 1.8$ & $\begin{array}{l}93.1 \pm 2.6 \\
(p<0.001)\end{array}$ & $94.0 \pm 2.8$ \\
\hline $\begin{array}{l}\text { Whole body } \\
\text { potassium (Meq) }\end{array}$ & $2781 \pm 88$ & $\begin{array}{l}3499 \quad \pm 88 \\
(p<0.001)\end{array}$ & $3462 \pm 83$ \\
\hline Body fat $(\mathrm{kg})$ & $20.0 \pm 2.1$ & $\begin{array}{l}41.8 \pm 2.1 \\
(p<0.001)\end{array}$ & $42.1 \pm 2.1$ \\
\hline
\end{tabular}

Means \pm SEM. Comparisons between controls and obese subjects

Table 2. Characteristics of examined groups (Study II)

\begin{tabular}{|c|c|c|c|c|}
\hline & \multicolumn{2}{|c|}{ Control subjects $(n=13)$} & \multicolumn{2}{|c|}{ Diabetic subjects $(n=33)$} \\
\hline & Before & After & Before & After \\
\hline Age (years) & $46.2 \pm 3.3$ & - & $49.8 \pm 2.1$ & - \\
\hline $\begin{array}{l}\text { Body weight } \\
\text { (kg) }\end{array}$ & $92.3- \pm 3.2$ & $91.2 \pm 3.2$ & $87.5 \pm 3.1$ & $88.0 \pm 3.1$ \\
\hline $\begin{array}{l}\text { Body cell } \\
\text { mass }(\mathrm{kg})\end{array}$ & $27.3 \pm 0.8$ & $27.0 \pm 0.7$ & $\begin{array}{l}31.6 \pm 1.3 \\
(p<0.05)\end{array}$ & $38.1 \pm 1.3$ \\
\hline $\begin{array}{l}\text { Body fat } \\
(\mathrm{kg})\end{array}$ & $44.2 \pm 2.3$ & $43.8 \pm 2.4$ & $\begin{array}{l}31.1 \pm 1.9 \\
(p<0.05)\end{array}$ & $31.2 \pm 2.0$ \\
\hline $\begin{array}{l}\text { Fat cell } \\
\text { number } \\
\left(10^{10}\right)\end{array}$ & $6.8 \pm 0.5$ & - & $\begin{array}{l}4.8 \pm 0.5 \\
(p<0.05)\end{array}$ & - \\
\hline $\begin{array}{l}\text { Fat cell } \\
\text { weight }(\mu \mathrm{g})\end{array}$ & $0.65 \pm 0.02$ & - & $0.65 \pm 0.03$ & - \\
\hline
\end{tabular}

Means \pm SEM. Comparisons between controls and Type 2 diabetic subjects

for $1 \mathrm{~h}$ at $37^{\circ} \mathrm{C}$ as previously described [10]. After filtration, the cells were carefully washed four times in fresh medium. Insulin binding to the cells was then measured using the method of Gammeltoft and Gliemann [11]. The cells were incubated for $45 \mathrm{~min}$ at $24^{\circ} \mathrm{C}$ with $0.5-1.0 \mathrm{ng} / \mathrm{ml}$ monocomponent ${ }^{125} \mathrm{I}$-insulin. Cold insulin added was present at the indicated concentrations. Tracer binding in the presence of $4.17 \mathrm{ng} / \mathrm{ml}(100000 \mu \mathrm{U} / \mathrm{ml})$ unlabelled insulin was considered nonspecific and subtracted from the results. Mean fat cell size was determined according to Smith et al. [10]. Mean fat cell surface area was calculated according to the formula:

$\mathrm{SA}=\left[\mathrm{d}^{2}+\mathrm{SD}^{2}\right] \pi$ : where SA $=$ surface area, $\overline{\mathrm{d}}=$ mean fat cell $\mathrm{di}-$ ameter, and SD the standard deviation.

\section{Lipolysis and glucose incorporation into triglycerides}

After preincubating tissue fragments (average weight $10 \mathrm{mg}$ ) for $30 \mathrm{~min}$, the incubations were performed for $2 \mathrm{~h}$ at $37^{\circ} \mathrm{C}$ in fresh medium 199 containing $1 \mathrm{mmol}$ glucose, $40 \mathrm{~g} / 1$ bovine serum albumin, $0.15 \mu \mathrm{Ci} / \mathrm{ml}\left(\mathrm{U}_{-}{ }^{14} \mathrm{C}\right)$-glucose and noradrenaline $\left(10^{-5} \mathrm{M}\right)$, and different concentrations of insulin. Glycerol release to the incubation medium, analyzed according to Laurell and Tibbling [12], was taken as an index of lipolysis. Triglycerides were extracted according to Dole [13] and the radioactivity counted. These studies were performed in 12 control and 18 diabetic subjects who gave their informed consent.

Glucagon-poor insulin was generously supplied by Eli Lilly and Co, (Indianapolis, Ind., USA). Medium 199 was obtained from Stat- ens Bakteriologiska Laboratorium, (Stockholm, Sweden). Collagenase, type I, bovine serum albumin, fraction V, and norepinephrine bitartrate were from Sigma (St.Louis, Mo., USA). U- ${ }^{14} \mathrm{C}$-glucose $(4 \mathrm{mCi} / \mathrm{mmol})$ was obtained from New England Nuclear Corporation (Boston, Mass., USA), and ${ }^{125} \mathrm{I}$-monocomponent insulin (specific activity about $190 \mu \mathrm{Ci} / \mathrm{ug}$ ) was a generous gift from Dr. S. Ivarsson, Malmö, Sweden.

\section{Statistical methods}

Intra-individual differences, comparing results before and after the training period as well as differences between groups, were tested using the Student's $t$-test.

\section{Results}

\section{Study I}

As seen in Table 1, physical training was not followed by any changes in body composition. All subjects following the training programme showed increases in $\mathrm{VO}_{2}$ max. and/or decreases of heart rate on a submaximal work load (not shown).

Table 3 shows that the fasting glucose values and sum of the glucose values during glucose tolerance test were higher in the group of all obese subjects than in controls $(p<0.05)$. The sum of insulin values during glucose tolerance test was also higher in the obese group $(p<0.01)$ but the C-peptide values were not.

Physical training in the entire group of obese subjects was not followed by any changes in glucose or insulin, while the sum of C-peptide concentrations decreased.

Figure $1 \mathrm{a}$ shows the $\mathrm{C}$-peptide values before and after physical training $(r: 0.72 p<0.01)$ and Figure $1 \mathrm{~b}$ the correlation between the changes in C-peptide and the pretraining values $(r: 0.28, p<0.05)$. There were no correlations between the changes of insulin and glucose concentrations with their respective pretraining values (not shown).

To further analyse this phenomenon the obese subjects were divided into three groups with low, normal or high insulin secretion, utilizing the sum of C-peptide values of the controls as dividing line. The obese subjects with C-peptide concentrations within the mean \pm 2 SD of the controls were called normal insulin secretors (NIS), those below or above these limits were low high insulin secretors (LIS and HIS groups respective1y). As seen in Table 3 these groups did not differ in glucose tolerance, but the obesity HIS group had higher insulin values than the other groups $(p<0.05)$. With physical training no changes occurred in neither blood glucose nor insulin values in any of these groups. C-peptide values decreased in the HIS group and NIS group (only sum of C-peptide values), and increased in the LIS group (Table 3 ). There were no differences in body weight, body fat and total body potassium between the groups and no changes with physical training (not shown). 
Table 3. Effects of physical training on glucose tolerance and plasma insulin and C-peptide concentrations (Study I)

\begin{tabular}{|c|c|c|c|c|c|}
\hline & $\begin{array}{l}\text { Control subjects } \\
(n=15)\end{array}$ & $\begin{array}{l}\text { Obesity all } \\
(n=55)\end{array}$ & $\begin{array}{l}\text { Obesity HIS } \\
(n=15)\end{array}$ & $\begin{array}{l}\text { Obesity NIS } \\
(n=22)\end{array}$ & $\begin{array}{l}\text { Obesity LIS } \\
(n=14)\end{array}$ \\
\hline \multicolumn{6}{|c|}{ Fasting glucose $(\mathrm{mmol} / \mathrm{l})$} \\
\hline Before & $3.9 \pm 0.1$ & $4.4 \pm 0.1$ & $4.6 \pm 0.2$ & $4.4 \pm 0.2$ & $4.2 \pm 0.1$ \\
\hline After & - & $4.3 \pm 0.1$ & $4.6 \pm 0.2$ & $4.3 \pm 0.2$ & $4.1 \pm 0.2$ \\
\hline$p$ & & NS & NS & NS & NS \\
\hline \multicolumn{6}{|c|}{ Sum of glucose $(\mathrm{mmol} / \mathrm{l})$} \\
\hline Before & $22.8 \pm 1.1$ & $31.5 \pm 1.1$ & $32.6 \pm 1.8$ & $32.4 \pm 2.2$ & $29.4 \pm 1.6$ \\
\hline After & - & $30.5 \pm 1.2$ & $32.5 \pm 2.6$ & $31.3 \pm 2.3$ & $28.1 \pm 1.4$ \\
\hline$p$ & - & NS & NS & NS & NS \\
\hline \multicolumn{6}{|c|}{ Fasting insulin (nmol/l) } \\
\hline Before & $0.11 \pm 0.06$ & $0.12 \pm 0.01$ & $0.16 \pm 0.02$ & $0.11 \pm 0.01$ & $0.09 \pm 0.01$ \\
\hline After & - & $0.11 \pm 0.01$ & $0.16 \pm 0.02$ & $0.10 \pm 0.01$ & $0.08 \pm 0.01$ \\
\hline$p$ & - & NS & NS & NS & NS \\
\hline \multicolumn{6}{|c|}{ Sum of insulin (nmol/1) } \\
\hline Before & $1.00 \pm 0.10$ & $2.30 \pm 0.13$ & $2.99 \pm 0.28$ & $2.06 \pm 0.15$ & $2.04 \pm 0.22$ \\
\hline After & - & $2.12 \pm 0.14$ & $2.89 \pm 0.33$ & $2.00 \pm 0.20$ & $1.70 \pm 0.16$ \\
\hline$p$ & - & NS & NS & NS & NS \\
\hline \multicolumn{6}{|c|}{ Fasting C-peptide (nmol/1) } \\
\hline Before & $0.32 \pm 0.03$ & $0.39 \pm 0.03$ & $0.67 \pm 0.04$ & $0.40 \pm 0.03$ & $0.13 \pm 0.02$ \\
\hline After & - & $0.36 \pm 0.03$ & $0.61 \pm 0.04$ & $0.35 \pm 0.04$ & $0.19 \pm 0.05$ \\
\hline$p$ & - & NS & $0.10>p>0.05$ & NS & $0.10>p>0.05$ \\
\hline \multicolumn{6}{|c|}{ Sum of C-peptide (nmol/1) } \\
\hline Before & $5.11 \pm 0.31$ & $4.86 \pm 0.42$ & $8.91 \pm 0.32$ & $4.84 \pm 0.33$ & $1.51 \pm 0.18$ \\
\hline After & - & $4.15 \pm 0.46$ & $7.51 \pm 0.60$ & $3.78 \pm 0.63$ & $2.35 \pm 0.67$ \\
\hline$p$ & - & $p<0.05$ & $p<0.05$ & $p<0.05$ & $p<0.05$ \\
\hline
\end{tabular}
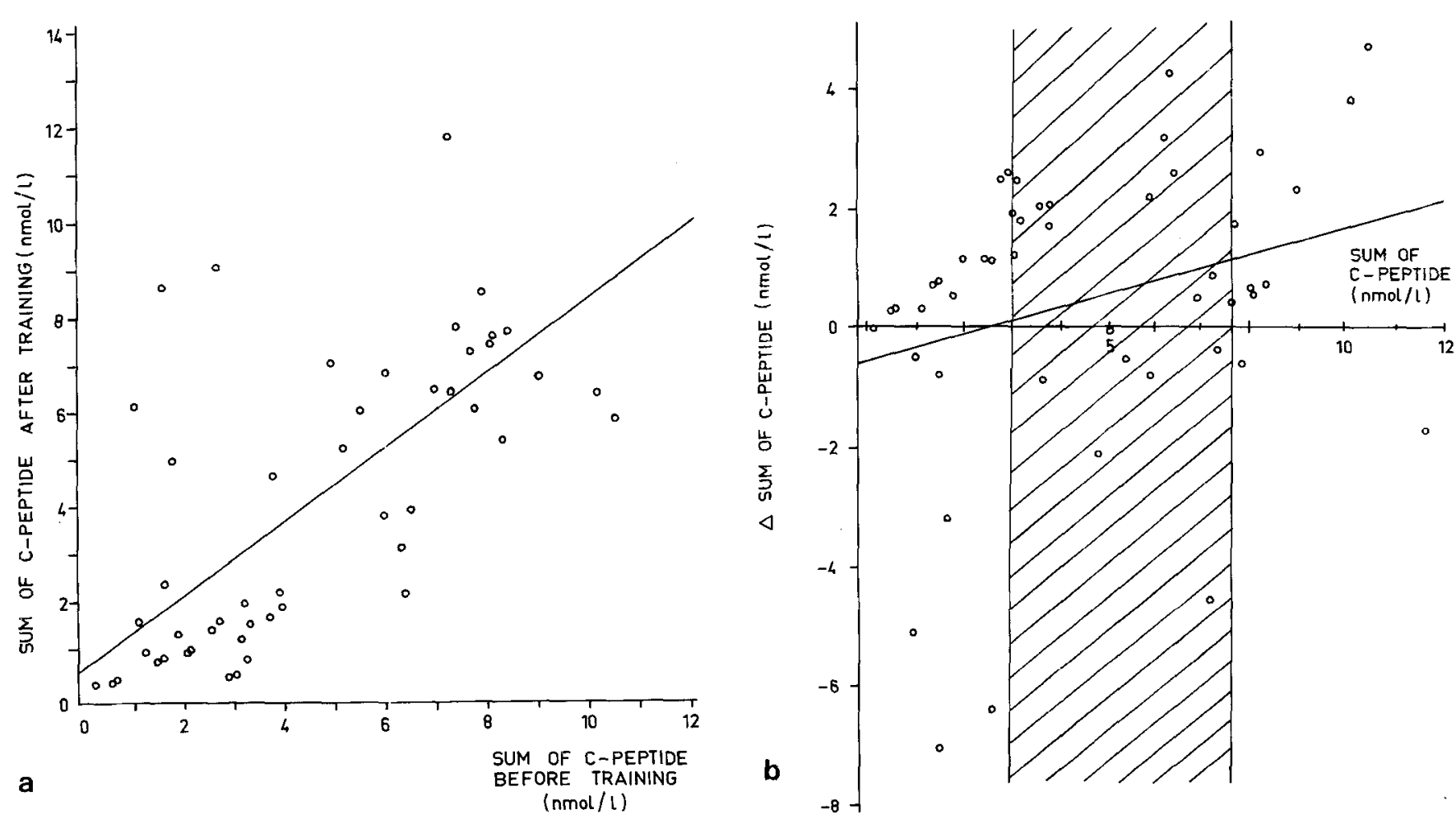

Fig. 1. a The relationship between the sum of plasma C-peptide concentrations during glucose tolerance test before and after physical training in obese subjects. $y=0.55+0.78 x ; r: 0.72 ; p<0.01$ (Study I). b The relationship between the sum of plasma C-peptide concentrations during glucose tolerance test before training and the change in these values with physical training in obese subjects. $\mathrm{y}=-0.55+0.22 \mathrm{x} ; r: 0.28 ; p<0.05$. Shaded area: Mean \pm 2 SD of values for nonobese controls (Study I) 


\section{Study II}

Table 2 shows that age, body weight and average fat cell size did not differ between the non-diabetic and diabetic subjects. The diabetic subjects had higher body cell mass, less body fat and fewer fat cells than the non-diabetic subjects. None of these variables changed with physical training.

A mean increase was seen in maximal oxygen uptake following training, while heart rate and blood pressure decreased both at rest and during submaximal work (Table 4). Examining individual data, five diabetic subjects did not show any evidence of physical training in neither $\mathrm{VO}_{2}$ max nor heart rate during submaximal

Table 4. Circulatory variables of examined groups before and after physical training (Study II)

\begin{tabular}{|c|c|c|c|c|c|c|c|c|}
\hline & \multicolumn{4}{|c|}{$\begin{array}{l}\text { Control subjects } \\
(n=13)\end{array}$} & \multicolumn{4}{|c|}{$\begin{array}{l}\text { Diabetic subjects } \\
(n=33)\end{array}$} \\
\hline & \multicolumn{2}{|c|}{ Before } & \multicolumn{2}{|c|}{ After } & \multicolumn{2}{|c|}{ Before } & \multicolumn{2}{|c|}{ After } \\
\hline $\begin{array}{l}\mathrm{VO}_{2} \max \\
(1 / \min )\end{array}$ & \multicolumn{2}{|c|}{$2.23 \pm 0.14$} & \multicolumn{2}{|c|}{$2.62 \pm 0.20^{b}$} & \multicolumn{2}{|c|}{$2.27 \pm 0.14$} & \multicolumn{2}{|c|}{$2.59 \pm 0.13^{c}$} \\
\hline \multicolumn{9}{|c|}{ Heart rate (beats/min) } \\
\hline Rest & 86 & \pm 4 & 77 & $\pm 4^{\mathrm{a}}$ & 83 & \pm 3 & 72 & $\pm 3^{\mathrm{c}}$ \\
\hline $\begin{array}{l}\text { Work } \\
\qquad(50 \mathrm{~W})\end{array}$ & 116 & \pm 4 & 115 & \pm 4 & 113 & \pm 4 & 105 & $\pm 4^{\mathrm{a}}$ \\
\hline $\begin{array}{l}\text { Work } \\
\qquad(100 \mathrm{~W})\end{array}$ & 147 & \pm 5 & 141 & \pm 4 & 140 & \pm 4 & 123 & $\pm 4^{\mathrm{b}}$ \\
\hline \multicolumn{9}{|c|}{$\begin{array}{l}\text { Systolic blood pressure } \\
(\mathrm{mm} \mathrm{Hg})\end{array}$} \\
\hline Rest & 140 & \pm 4 & 131 & $\pm 4^{a}$ & 144 & \pm 4 & 143 & \pm 4 \\
\hline $\begin{array}{l}\text { Work } \\
\qquad(50 \mathrm{~W})\end{array}$ & 150 & \pm 3 & 145 & \pm 4 & 160 & \pm 4 & 152 & $\pm 4^{\mathrm{a}}$ \\
\hline $\begin{array}{l}\text { Work } \\
\qquad(100 \mathrm{~W})\end{array}$ & 179 & \pm 5 & 157 & $\pm 6^{a}$ & 188 & \pm 6 & 178 & $\pm 5^{\mathrm{a}}$ \\
\hline
\end{tabular}

Means \pm SEM. Comparisons between results before and after physical training.

${ }^{\mathrm{a}} p<0.05 ; \quad{ }^{\mathrm{b}} p<0.01 \quad{ }^{\mathrm{c}} p<0.001$ work load. These subjects were therefore excluded from further analyses.

The blood glucose levels were higher in the diabetic than the non-diabetic subjects (Table 5). Plasma concentrations of C-peptide as well as of insulin during OGTT were lower in the diabetic group. Plasma lipids were not different.

With physical training the plasma C-peptide concentrations during the glucose tolerance test decreased in the nondiabetic subjects. In contrast, in the diabetic group, C-peptide concentrations increased. Glucose intolerance improved in the diabetic group. Insulin or lipid values did not change in any of the groups.

Comparisons between the diabetic subjects who were treated with sulfonylurea or not showed higher glucose values and lower $\mathrm{C}$-peptide values in the former, but otherwise no differences were found. Both showed the same response to physical training. Furthermore, no difference in response to physical training was seen between men and women (not shown).

Analogous to the non-diabetic obese subjects in Study I the change in sum of C-peptide values during OGTT correlated significantly with the C-peptide values before commencing the training program as seen in Figure 2. It is also seen that this correlation was mainly due to an increase during physical training of low values, particularly those which before training were below the normal range. Here the average values increased dramatically from $1.93 \pm 0.14 \mathrm{nmol} / 1$ before training to $6.09 \pm 1.43 \mathrm{nmol} / 1$ after training $(p<0.001)$. There were no significant changes in insulin in this subgroup or in the remaining subjects.

\section{Euglycaemic glucose clamp studies}

The results of the euglycaemic glucose clamp studies are shown in Fig. 3. The glucose disposal rate was simi-

Table 5. Metabolic variables of examined groups before and after physical training (Study II)

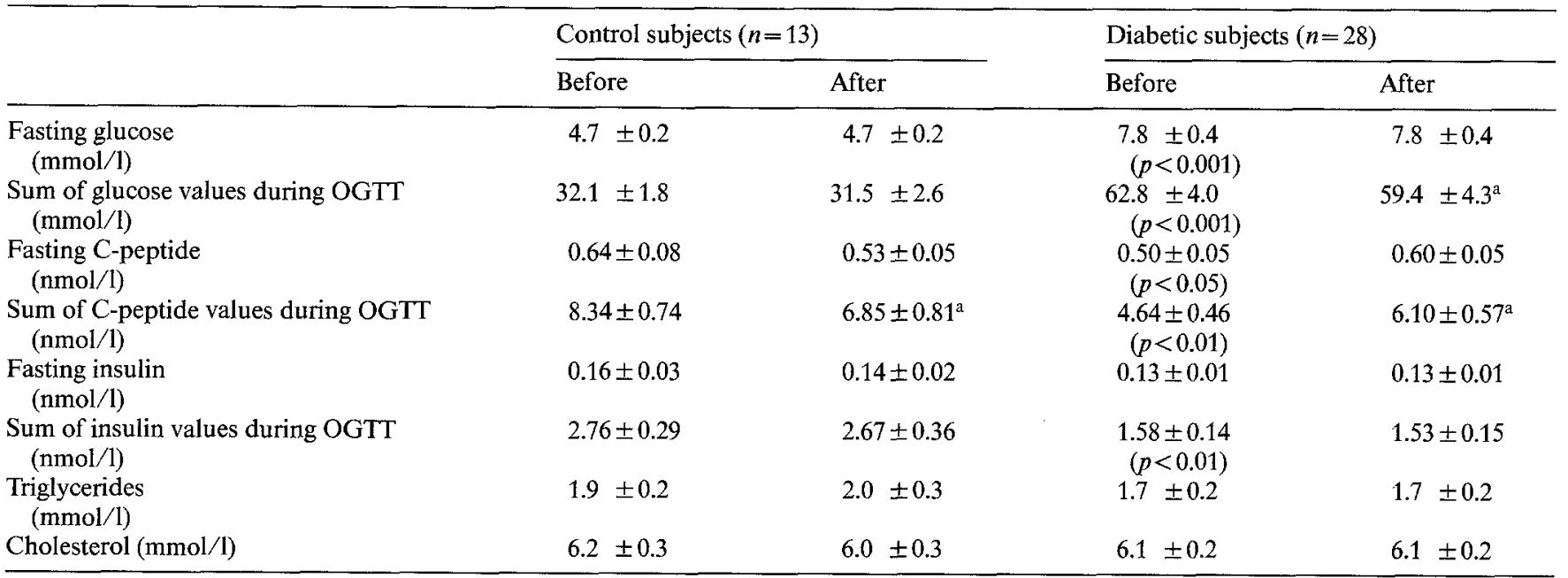

OGTT: Oral glucose tolerance test.

Means \pm SEM Comparisons between control and diabetic subjects (within parentheses) and between results before and after physical training. a $p<0.05$ 
lar in the diabetic and non-diabetic groups at both low and high insulin infusion rates. Physical training increased the glucose disposal rate in both groups, and at both insulin infusion rates. There was a positive, significant correlation between improvement in glucose tolerance (sum of glucose values during OGTT before - after) and the glucose disposal rate (per kg LBM) in the glucose clamp studies in the diabetic group $(r: 0.65, p<$ 0.01 ).

\section{Adipose tissue studies}

Figure 4 depicts the data of insulin binding to adipocytes. There were no significant differences in insulin binding between the groups, neither before nor after physical training. There was no change in binding after the training period.

Figure 5 shows the insulin effect on glucose incorporation into triglycerides before and after training. Adipocytes from diabetic patients showed less incorporation than from controls before training $(p<0.05)$. The non-diabetic group showed no change with training. In the diabetic group, however, the insulin stimulated glucose incorporation was significantly increased after physical training.

Basal and noradrenaline-stimulated lipolysis as well as the antilipolytic response of insulin, were similar in both groups, and were not significantly changed by the training period. Insulin sensitivity, evaluated as the insulin concentration giving half-maximal antilipolytic effect, was also unchanged following the training period (data not shown).

\section{Discussion}

C-peptide and insulin are released from the B cell in equimolar amounts $[14,15]$. In contrast to insulin, Cpeptide is not taken up by the liver in animals $[16,17]$ or in man $[18,19]$. Measurements of C-peptide concentrations in peripheral blood therefore give a better estimate of insulin secretion than measurements of peripheral insulin concentrations. The validity of evaluating insulin secretion by C-peptide concentration measurements depends, however, on several additional prerequisites. First, metabolic clearance rate (MRC) has to be known to allow transformations of concentration to actual secretion of insulin and C-peptide. If this is not known, MCR has at least to be constant in different conditions, and comparable between different groups.

MCR of C-peptide does not change with stimulation of insulin secretion. Uptake is apparently not occurring in muscle and adipose tissue, and the main excretory route is via the kidneys [20]. Urinary clearance of C-peptide is essentially independent of the plasma Cpeptide concentration, and similar in normal weight, obese and diabetic subjects in relation to creatinine secretion [21, 22], and MCR of C-peptide is not different

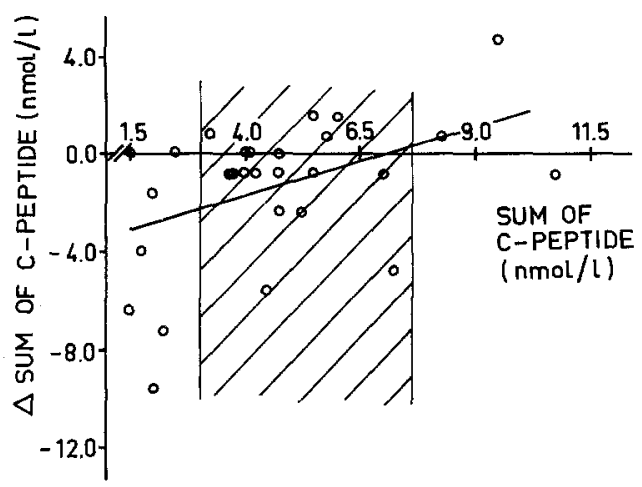

Fig. 2. The relationship between the sum of plasma C-peptide concentrations during glucose tolerance test before training and the change in these values with physical training in patients with Type 2 diabetes. $y=-4.26+0.603 x ;=0.35 p t b<0.01$. Shaded area; Mean \pm 2 SD of values for non-obese controls (Study II)

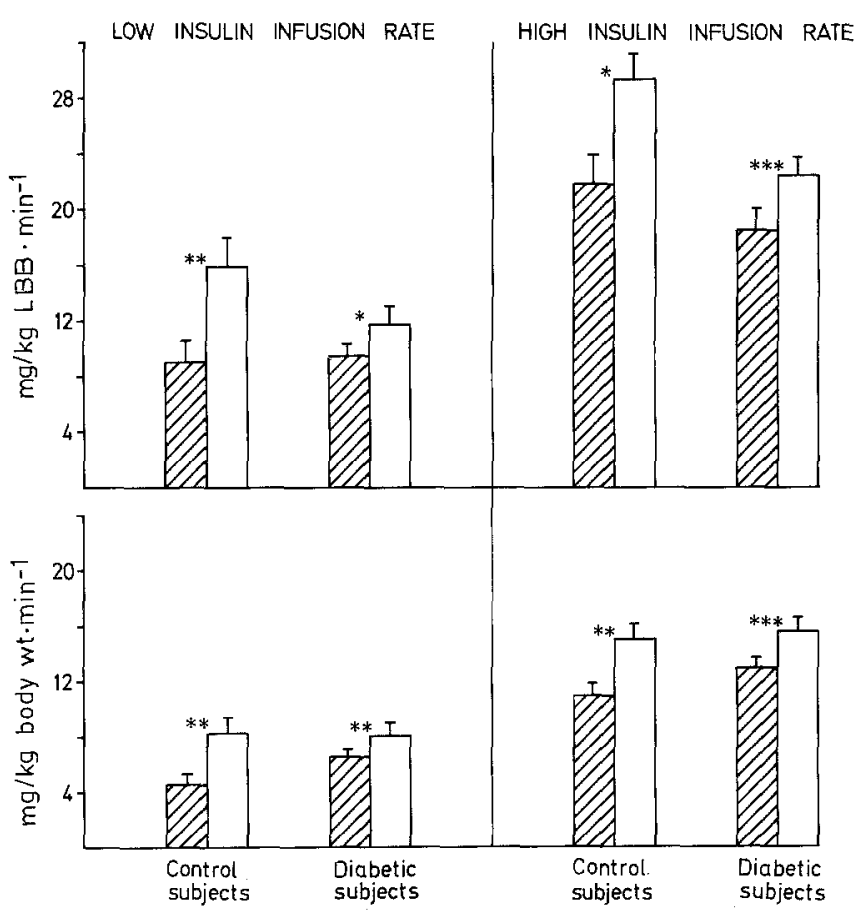

Fig.3. Glucose disposal rate in diabetic and control subjects during euglycaemic clamp before (hatched bars) and after (open bars) physical training at two different insulin infusion rates (69-165 and $810-2350 \mathrm{mU} / \mathrm{min}$, respectively).

$* p<0.05 ; \quad * * p<0.001 ; * * * p<0.001$. (Means \pm SEM)

$n=13$ and $n=10$ for control and diabetic patients respectively (Study II)

between non-diabetic and diabetic subjects [23]. Taken together this information seems to make it possible to conclude that C-peptide secretion from the B cell is equivalent to insulin secretion, and that liver uptake does not invalidate estimation of insulin secretion from C-peptide determinations. In summary, this means that the plasma C-peptide concentrations in the present work probably are useful indices of insulin secretion.

The correlation between the decrease and initial value of C-peptide (Fig. 1b) is partly a statistical artefact 

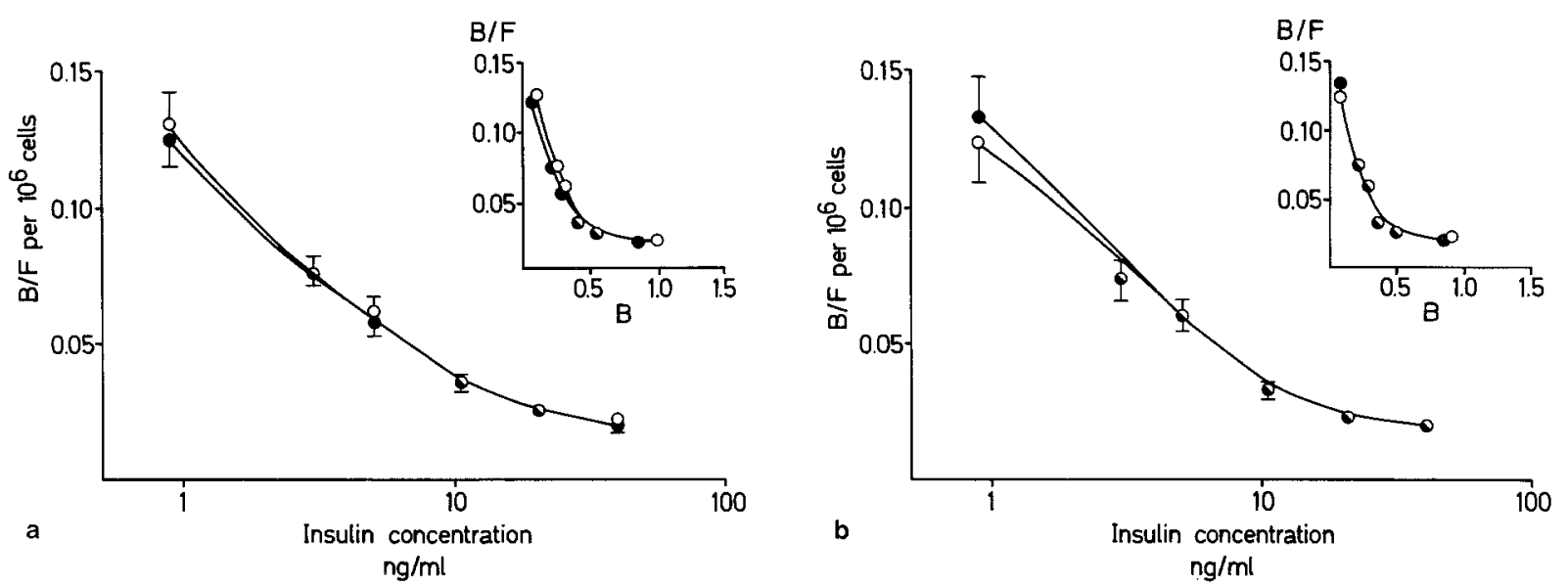

Fig. 4 a and b. Specific ${ }^{125}$ I-insulin binding to adipocytes in a diabetic and $\mathbf{b}$ control subjects before (open circles) and after (filled circles) physical training. Inserted are shown the Scatchard plots. Bound insulin expressed as ng $/ 10^{6}$ cells. (Means \pm SEM) $n=12$ and $n=17$ for control and diabetic subjects, respectively (Study II)

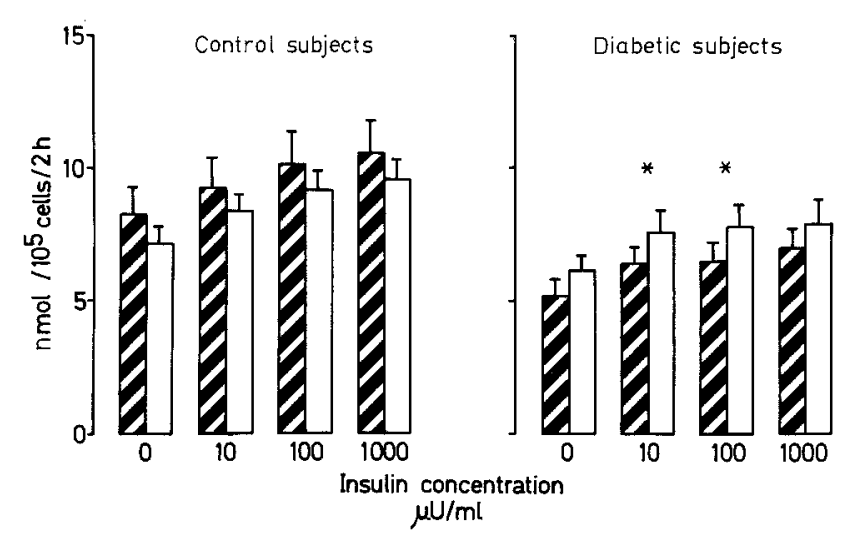

Fig.5. Basal and insulin stimulated $\mathrm{U}^{14} \mathrm{C}$-glucose incorporation into triglycerides in diabetic and control subjects before (hatched bars) and after (open bars) physical training.

* $p<0.05$. (Means \pm SEM).

$n=12$ and $n=18$ for control and diabetic subjects, respectively (Study II)

(regression towards the mean) caused by the random errors (measurement errors and intraindividual variation). If the standard deviation of the random errors were known it would be possible to compute to what extent the observed correlation is a biological reality. Lacking such precise information we can investigate whether the observed correlation can possibly be caused by the random errors alone. Such computations show that with the coefficient of variation of the random errors equal to $10 \%$ the (false) correlation would be 0.03 and with a variation of $20 \%$ the correlation would be 0.12 . A correlation coefficient 0.28 can thus hardly be an effect of regression towards the mean. The observation must, however, be considered as a rather weak indication of a biological relationship since one has also to take into account the sampling errors in the correlation coefficient. The observed value differs from zero only at the $5 \%$ significance level.
These considerations thus make it unlikely that the observed correlation was explainable other than to a minor degree by a statistical artefact. Therefore further analyses were performed with the material of obese subjects divided into groups with normal, low and high C-peptide values using control values as guidance.

Hyperinsulinaemia was found in all the subgroups of obesity (Table 3). Hypersecretion of insulin was, however, found only in the HIS group, while in the LIS group the insulin secretion was markedly low. These findings indicate different causes to the hyperinsulinaemia in obesity. One possible explanation might be found in differences in the liver uptake of insulin. If this is the main explanation the molar ratios of insulin and C-peptide concentrations in Table 3 suggest that very little of secreted insulin is taken up in the liver in the LIS group, while the liver uptake in the NIS and HIS groups would be approximately $60 \%$ and $70 \%$ respectively (sum of values). These observations confirm previous reports $[24,25]$.

In the total group of obese, non-diabetic subjects (study I) physical training was followed by only limited changes in the metabolic and hormonal variables. When divided into subgroups according to the initial insulin secretion, as indicated by C-peptide concentrations, it was found, however, that high and normal insulin secretors showed a decreased secretion after physical training. This was also the case with the obese controls in study II, who were on an average high insulin secretors with similar C-peptide values as the obesity HIS group in study I. This has been observed repeatedly before by measurements of insulin $[4,26,27]$ and Cpeptide [28]. In obese subjects with low insulin secretion, however, physical training was followed by increased C-peptide values. Confirming previous studies $[4,28]$, no changes were seen in glucose tolerance or in body composition variables.

Patients with diabetes mellitus improved their glucose tolerance with physical training. This occurred 
without changes in body composition and plasma insulin. C-peptide concentrations increased, however. A closer analysis of this phenomenon revealed that this increase was most pronounced in those patients who initially had the lowest C-peptide values, again indicating that physical training in this situation actually causes an increase of a low insulin secretion.

Taken together these data then indicate that in conditions with insulin hypersecretion, physical training results in a decreased insulin secretion. In contrast, in subjects with abnormally low insulin secretion this is elevated after physical training. Insulin hypersecretion is usually considered to be the result of a compensation for an increased peripheral insulin resistance. When this resistance is lowered by physical training, as evidenced here by the glucose clamp studies, then consequently insulin secretion decreases. It is less clear why insulin secretion increases after physical training in conditions with low insulin secretion. It has previously been shown that physical training is followed by an increased sensitivity in both the cholinergic [29] and B-adrenergic [30] nervous systems, both stimulating insulin secretion. It is therefore suggested that this increased sensitivity is the cause to the increased insulin production after physical training in conditions with low insulin secretion reported here.

The changes in C-peptide concentrations after physical training were much more pronounced than those in insulin. Neither when an elevated C-peptide concentration was lowered nor when $\mathrm{C}$-peptide values were increased were insulin concentrations in the periphery different after training as compared with before. The unchanged peripheral insulin concentrations in spite of alterations in insulin secretion indicate that the uptake of insulin in the liver and/or periphery was altered.

Insulin clearance did not differ after as compared with before training as measured with the glucose clamp technique (data not shown), indicating that changes in the removal of insulin in the periphery was not changed by physical training. This in turn suggests that the uptake of insulin in the liver changed. In the case of an increased, low insulin secretion this then probably meant that the liver uptake of insulin had increased. This suggestion is supported by the fact that insulin uptake in the liver is dependent on the portal concentration of insulin [31], in turn dependent on insulin secretion. It seems reasonable to assume that this extra production of insulin after physical training, captured by the liver, contributed to the improvement of glucose intolerance seen in the diabetic subjects where the initial insulin secretion was subnormal.

\section{Euglycaemic clamp studies}

The glucose disposal rate estimated by the euglycaemic clamp showed no difference between the groups with or without diabetes mellitus, indicating a similar peripheral insulin effect on glucose uptake in these groups which both were somewhat obese. The fact that the diabetic group did not appear resistant to insulin as compared to the non-diabetic group does not mean that they were normal with regard to insulin sensitivity and responsiveness. Rather insulin resistance was probably equally present in both groups. This was, however, improved by physical training to a similar extent in both groups. From other studies it is known that insulin sensitivity is increased in muscles during contraction [32, 33] or after physical training [34], while this does not seem to be the case in the liver [34]. The effects of physical training seen in the glucose clamp studies were then presumably mainly due to an increase of glucose uptake in muscles [35]. Although an increase of peripheral effectiveness of insulin occurred in both groups, it was only in the diabetic subjects that glucose tolerance improved. The improvement in glucose tolerance correlated with the increase in glucose disposal rate in the clamp measurement in the diabetic group. Whether these phenomena are causally related remains to be clarified, but this seems at least to be a reasonable possibility.

\section{Adipose tissue studies}

Adipose tissue only plays a minor role for total body glucose homeostasis, as compared to muscles and liver [36]. However, since insulin sensitivity and responsiveness in fat cells seem to reflect the severity of glucose intolerance in diabetic subjects [37,38], it may be of interest to compare data obtained from adipocytes in vitro with those found with the glucose clamp technique. Therefore, to further elucidate the cellular mechanisms explaining the higher rate of glucose disposal following physical training, studies on abdominal fat cells were performed.

Insulin binding has been found not to deviate from normal in fat cells from obese and Type 2 diabetic patients $[37,38]$. The present study confirms these results. Furthermore, insulin binding was not changed following physical training in accordance with previous reports $[39,40]$. In monocytes an increased binding has been found [41, 42], but these cells are not natural target cells for insulin and, therefore, such data are less readily interpreted. Increased insulin binding to fat cells has been reported after physical training in rats [43]. A recent study seems to resolve this controversy showing that the increase in insulin binding, when found after physical training, is of such small magnitude that it has no obvious physiological significance in comparison with the increase in glucose transport [44].

Differences in insulin binding are reflected by a shift of the dose-response curve for insulin (altered insulin sensitivity) whereas a change in the maximal insulin effect (insulin responsiveness) mirrors postreceptor defect(s) [45]. Accordingly, insulin binding and insulin sensitivity, measured as the antilipolytic effect, were not changed in this study. In contrast, insulin responsive- 
ness, as indicated by the maximal glucose incorporation into triglycerides, was significantly improved after physical training in the diabetic patients.

Increased glucose transport capacity has been found previously in fat cells from trained rats [44]. The glucose clamp data indicate that physical training results in an increased insulin responsiveness, because glucose disposal rate was increased both at the low (submaximal) and the high (maximal) insulin infusion rates. Adipose tissue data then also show that the effect of training on the insulin responsiveness of glucose metabolism is due to postreceptor changes, and with no changes in insulin binding. These parallel findings suggest that, following physical training, similar reactions are occurring in other tissues where glucose uptake is quantitatively more significant than in adipose tissue.

The insulin resistance in fat cells from Type 2 diabetic subjects is mainly due to a diminished insulin responsiveness of glucose metabolism, probably due to a postreceptor-defect of glucose transport [37, 38]. Hence, it is suggested that when physical training causes a reversal of this postreceptor defect, an improvement in glucose tolerance is obtained.

In conclusion, this study has shown that an improvement of glucose tolerance is obtained when moderately obese, diabetic subjects have been trained physically. Previous studies $[1,2]$ and studies appearing while this work was in progress [47-49] have shown varying results, which may be due to the fact that different subgroups of Type 2 diabetic patients react differently to physical training. The effect is probably partly due to an increase of the insulin effectiveness on peripheral glucose uptake, presumably of main quantitative importance in muscles. This improvement is accentuated by an increase of low insulin secretion, probably resulting in better insulinization of the liver. Taken together this then indicates that physical training improves glucose tolerance by increasing insulin effects both in the peripheral tissues (by increased tissue responsiveness, due to a reversal of a postreceptor defect), and in the liver (by uptake of an increased insulin secretion).

Finally, it should be emphasized that the present study has shown an improvement of glucose tolerance by physical training in the absence of body composition changes. When body fat decreases in physical training programs, the effects on glucose tolerance and glucose homeostasis are probably more pronounced [46].

Acknowledgements. The statistical advice of N. Blomqvist, Ph. D., Department of Statistics, University of Göteborg is gratefully acknowledged. This study was supported by the Swedish Medical Research Council (project no. B 85-19X-6863-02), Nordic Foundation for Research without Animals, Greta and Einar Asker's Foundation and Hjalmar Svensson's Foundation.

\section{References}

1. Ruderman NB, Ganda OP, Johansen K (1979) The effect of physical training on glucose tolerance and plasma lipids in maturity-onset diabetes. Diabetes 28 (Suppl 1): 89-92
2. Saltin B, Lindgärde F, Houston $M$, Horlin R, Nygaard E, Gad P (1979) Physical training and glucose tolerance in middle-aged men with chemical diabetes. Diabetes 28 (Suppl 1) 30-32

3. Costill DL, Cleary P, Fink WJ, Foster G, Ivy JL, Witzmann F (1979) Training adaptations in skeletal muscle of juvenile diabetics. Diabetes 28: 818-822

4. Björntorp P, de Jounge K, Sjöström L, Sullivan L (1970) The effect of physical training on insulin production in obesity. Metabolism. 19: 631-638

5. National diabetes data group. National Institute of Health, Bethesda Maryland USA (1979) Classification and diagnose of diabetes mellitus and other categories of glucose intolerance. Diabetes 2: 1031-1057

6. Sköldborn H, Arvidsson B, Andersson M (1972) A new whole body monitoring laboratory. Acta Radiol 313 (Suppl): 233-241

7. Forbes GB, Gallup J, Hurch JB (1961) Estimation of total body fat from potassium-40 content. Science 133: 101-102

8. Sjöström L, Björntorp P, Vrana J (1971) Microscopic fat cells size measurements on frozen-cut adipose tissue in comparison with automatic determinations of osmium-fixed fat cells. J Lipid Res 12: $521-530$

9. Astrand I (1960) Aerobic work capacity in men and women with special reference to age. Acta Physiol Scand 49 (Suppl) 169

10. Smith U, Sjöström L, Björntorp P (1972) Comparison of two methods to determine human adipose cell size. J Lipid Res 13: 822-824

11. Gammeltoft S, Gliemann J (1973) Binding and degradation of 125-I-insulin by isolated rat fat cells. Biochem Biophys Acta 320: 16-32

12. Laurell S, Tibblin G (1966) An enzymatic fluorimetric micromethod for the determination of glycerol. Clin Chim Acta 13:317-322

13. Dole VP, Meinerts H (1960) Microdetermination of long-chain fatty acids in plasma and tissue. $\mathrm{J}$ Biol Chem 235:2595-2599

14. Heding LG, Larsen OD, Markussen J, Jørgensen KH, Hallund O (1974) Radioimmunoassays for human, pork and of C-peptide and related substances. Horm Metab Res 5 (Suppl): 40-44

15. Horwitz DL, Starr JI, Mako ME, Blackard WE, Rubenstein AH (1975) Proinsulin, insulin and C-peptide concentrations in human portal and peripheral blood. J Clin Invest 55: 1278-1283

16. Stoll RW, Touber JL, Menahan LA, Williams RH (1970) Clearance of porcine insulin, proinsulin and connecting peptide by the isolated rat liver. Proc Soc Exp Biol Med 111: 894-896

17. Katz AI, Rubenstein AH (1973) Metabolism of proinsulin, insulin and C-peptide in the rat. J Clin Invest 52:1113-1121

18. Canivet B, Krebs BP (1980) C-peptide uptake and excretion by the liver in man. Horm Metab Res 12: 229-230

19. Bratusch-Marain PR, Waldhäusl WK, Gasic S, Hofer A (1984) Hepatic disposal of biosynthetic human insulin and porcine C-peptide in humans. Metabolism 33: 151-157

20. Faber OK, Kehlet H, Madsbad S, Binder C (1978) Kinetics of human C-peptide in man. Diabetes 27 (Suppl 1): 207-209

21. Blix PM, Boddie-Willis C, Landau RL, Rochman H, Rubenstein AH (1982) Urinary C-peptide; an indicator of beta-cell secretion under different metabolic conditions. J Clin Endocrinol Metab 54: $574-580$

22. Meistas MT, Rendell M, Margolis S, Kowarski AA (1982) Estimation of the secretion rate of insulin from the urinary excretion rate of C-peptide. Study in obese and diabetic subjects. Diabetes 31 : 449-453

23. Faber OK, Hagen C, Binder C, Markussen J, Naithani VK, Blix PM, Kuzuya H, Horwitz DL, Rubenstein AH, Rossing N (1978) Kinetics of human connecting peptide in normal and diabetic subjects. J Clin Invest 62: 197-203

24. Rossell R, Gomis R, Casamitjana R, Segura E, Vilardell E, Rivera F (1983) Reduced hepatic insulin extraction in obesity: relationship with plasma insulin levels. J Clin Endocrinol Metab 56: 608-611

25. Malmquist J, Lindgärde F, Nordén G (1981) Plasma insulin and C-peptide in normal and glucose intolerant males: the role of hepatic insulin uptake. Acta Med Scand 656: 19-21

26. Björntorp P, Fahlén M, Grimby G, Gustafson A, Holm J, Renström P, Scherstén T (1972) Carbohydrate and lipid metabo- 
lism in middle-aged physically well-trained men. Metabolism 1: $1037-1044$

27. Lohmann D, Liebold F, Heilmann W, Stenger J, Pohl A (1978) Diminished insulin response in highly trained athletes. Metabolism 27: $521-524$

28. Krotkiewski M, Björntorp P, Holm G, Marks V, Morgan L, Smith U, Feurle GE (1984) Effects of physical training on insulin, connecting (c-peptide) gastric inhibitory polypeptide (GIP) and pancreatic polypeptide (PP) levels in obese subjects. Int $J$ Obesity 8: 193-199

29. Krotkiewski M, Sjöström L, Björntorp P (1980) Physical training in hyperplastic obesity. V. Effects of atropine on plasma insulin. Int J Obesity $4: 49-56$

30. Krotkiewski M, Mandroukas K, Morgan L, William-Olsson T, Feurle GE, von Schenk M, Björntorp P, Sjöström L, Smith U (1983) The effects of physical training on adrenergic sensitivity in obesity. J Appl Physiol 55: 1811-1847

31. Karakash C, Assimacopoulos-Jeannet F, Jeanrenaud B (1976) An anomaly of insulin removal in perfused livers of obese-hyperglycemic. (ob/ob) mice. J Clin Invest 57: 1117-1124

32. Holloszy JO, Narahara HT (1965) Studies on tissue permeability $\mathrm{X}$. Changes in permeability to 3-methylglucose associated with contraction of isolated frog muscle. J Biol Chem 240:3493 -3500

33. Berger M, Hagg S, Ruderman NB (1975) Glucose metabolism in perfused skeletal muscle. Biochem J 146: 221-238

34. Mondon CE, Dolkas CB, Reaven GM (1980) Site of enchanged insulin sensitivity in exercise-trained rats at rest. Am J Physiol 239: E169-E177

35. De Fronzo RA, Tobin JD, Andres R (1979) Glucose clamp technique; a method for quantifying insulin secretion and resistance. Am J Physiol 237: E214-E223

36. Björntorp P, Berchtold P, Holm J, Larsson B (1971) The glucose uptake of human adipose tissue in obesity. Eur $\mathrm{J}$ Clin Invest 1 : $480-485$

37. Lönnroth P, DiGirolamo M, Krotkiewski M, Smith U (1983) Insulin binding and responsiveness in fat cells from patients with reduced glucose tolerance and type II diabetes. Diabetes 32: $748-754$

38. Kashiwagi A, Verso MA, Andrews J, Vasques B, Reaven G, Foley JE (1983) In vitro insulin resistance of human adipocytes isolated from subjects with noninsulin-dependent diabetes mellitus. $\mathbf{J}$ Clin Invest 72: 1246-1254

39. Wirth A, Holm G, Nilsson B, Smith U, Björntorp P (1980) Insulin kinetics and insulin binding to adipocytes in physically trained and foodrestricted rats. Am J Physiol 238: E105-E115
40. Wardzala L, Horton E, Jeanrenaud B (1980) Physical training increases glucose transport and metabolism in rat adipose cells without altering insulin binding or sensitivity. Alim Nutr Metab 1: 376 (Abstract)

41. Soman V, Koivisto V, Diebert D, Felig P, de Fronzo R (1979) Increased insulin sensitivity and insulin binding to monocytes after physical training. N Engl J Med 301: 1200-1204

42. Koivisto V, Soman V, Conrad P, Hendler R, Nadel E, Felig P (1979) Insulin binding to monocytes in trained athletes. J Clin Invest 64: 1011-1015

43. Craig BW, Hammons GT, Gartwaite SM, Jarett J, Holloszy JO (1981) Adaptations of fat cells to exercise: response to glucose uptake and oxidation to insulin. J Appl Physiol 51: 1500-1506

44. Vinten H, Galbo H (1983) Effect of physical training on transport and metabolism of glucose in adipocytes. Am J Physiol E129-134

45. Kahn CR (1978) Insulin resistance, insulin intensitivity and insulin unresponsiveness; a necessary distinction. Metabolism 27 (Suppl 2): 1893-1902

46. Björntorp P, Berchtold P, Grimby G, Lindholm B, Sanne H, Tibblin G, Wilhelmsen L (1972) Effects of physical training on glucose tolerance, plasma insulin and lipids and on body composition in men after myocardial infarction. Acta Med Scand 192: $439-443$

47. Schneider SH, Amorosa LF, Khachadurian AK, Ruderman NB (1984) Studies on the mechanism of improved glucose control during regular exercise in Type 2 (non-insulin-dependent) diabetes. Diabetologia 26:355-360

48. Reitman JS, Vasquez B, Klimes I, Nagulesparan (1984) Improvement of glucose homeostasis after exercise training in non-insulindependent diabetes. Diabetes Care 7: 434-441

49. Trovati M, Carla Q, Cavarot F, Vitari S, Bonandi C, Lucchina PG, Fiocchi F, Emanuelli G, Lenti G (1984) Influence of physical training on blood glucose control, glucose tolerance, insulin secretion and insulin action in non-insulin-dependent diabetic patients. Diabetes Care 7: 416-420

Received: 9 October 1984

and in revised form: 30 September 1985

Dr. Per Björntorp

Department of Medicine I

Sahlgrenska Sjukhuset

S-41345 Göteborg

Sweden 